\title{
Efficiency of Chemical Ripener Action in Sugarcane. III. Growth and Qualitative Effects of Polaris as a Function of the Number and Frequency of Applications ${ }^{1}$
}

\begin{abstract}
Alex G. Alexander ${ }^{2}$
ABSTRACT

The efficiency of Polaris ( $\mathbb{N}, \mathbf{N}$-bis [phosphonomethyl] glycine) in modifying sugarcane quality, yield, and growth was studied with early-adult plants propagated in sand culture. A single quantity of the ripener administered in one dose served as the standard Polaris treatment. Identical quantities were applied as early increments $(0,3$, and 6 days) and as delayed increments $(0$, 15 , and 30 days). Other treatments supplied $1 / 3$ plus $2 / 3$ of the standard dose at 0 and 30 days, respectively, and in the reverse order of $2 / 3$ plus $1 / 3$. Early or delayed increments did not increase juice quality, but significantly increased juice yield over that obtained with a single dose. Juice yield was further increased by withholding $2 / 3$ of the standard dose for 30 days. Yield improvement is traced to an alleviation of growth and canopy-development restrictions imposed by the standard Polaris treatment. These responses are interpreted in terms of discrete qualitative and growth-regulatory roles of Polaris, in which growth repression continues to intensify at ripener levels in excess of those needed to attain optimal quality.
\end{abstract}

\section{INTRODUCTION}

Following an abundance of sugarcane ripener research during the 1950 's and 1960's, Polaris ${ }^{3.4}$ emerged as the first chemical ripener offering persistently predictable responses (3). These include a gradual improvement of juice quality, growth repression, and rapid decline of the acid invertases active in sugar utilization and storage processes. From an agronomic viewpoint, the increase of recoverable sucrose is the decisive response. This will vary with the variety and condition of treated cane, the quantity of applied material (5), and probably also with the season (7) and time of day (4) of its administration.

Chemical ripening requires distinct contributions from a range of source-to-sink processes, each having a finite capacity to be altered by chemical means. Within this context the extent to which a given dosage can be accommodated by plant systems for sugar manufacture, translocation, and storage remains obscure. For example, is a ripener most

${ }^{1}$ Manuscript submitted to the Editorial Board January 22, 1976.

${ }^{2}$ Plant Physiologist, Agricultural Experiment Station, University of Puerto Rico, Mayagüez Campus, Río Piedras, P.R.

${ }^{3}$ Monsanto Agricultural Products Co.

* Trade names are used in this publication solely for the purpose of providing specific information. Mention of a trade name does not constitute a guarantee or warranty of equipment or materials by the Agricultural Experiment Station of the University of Puerto Rico or an endorsement over other equipment or materials not mentioned. 
efficient when producing a single "shock" effect, or when its reception is dispersed over a period of several days? Is it possible to extend or improve ripener action with delayed increments offering "booster" effects? Further to this, can the plant be favorably sensitized, or "geared" for ripening, with a small quantity received prior to the main application?

The present study evaluates the responses to a single quantity of Polaris as a function of the number and frequency of its administrations.

\section{MATERIALS AND METHODS}

One-eye cuttings of the interspecific hybrid PR 980 were propagated in quartz sand as previously described (2). Polaris treatments were begun at 14 weeks of age. The ripener was administered as aqueous foliar sprays containing $0.10 \%$ Tween 20 as wetting agent. ${ }^{5}$ Application time was $0900 \mathrm{~h}$ and all leaves were thoroughly moistened.

The standard. Polaris treatment amounted to $1.5 \mathrm{~g}$ active ingredient administered as a single dose at "0 days." A second treatment consisted of three closely-spaced increments of $0.5 \mathrm{~g}$ each at 0,3 , and 6 days. Similarly, $0.5 \mathrm{~g}$ quantities were applied as delayed increments at 0, 15, and 30 days. Two additional treatments incorporated the standard dose as combined fractions of $1 / 3$ plus $2 / 3$, applied at 0 and 30 days, respectively, and in the reverse order of $2 / 3$ plus $1 / 3$. These combinations are summarized for clarity in table 1 . There were three replications of each treatment in an incomplete randomized block design.

Samples consisting of six uniform plants/replicate were harvested at $0700 \mathrm{~h}$ on "day 0," and at the same hour 49 days thereafter. Greenweight measurements were taken for whole plants, tops, and millable stems. Appropriate leaf and meristem samples were frozen for tissuecomponent analyses as described in a prior publication (2). At 49 days, the number of viable leaves (still green with the sheath fully encircling the stem) was recorded for each plant. Leaf rank ${ }^{+} 2$ was retained for blade area measurements. Chlorophyll was determined for leaf blade ${ }^{+} 1$ in accordance with Arnon (6). All data were submitted to statistical analysis by the Duncan New Multiple Range Test.

\section{RESULTS}

Juice quality was not appreciably altered by supplying Polaris in early or delayed increments (table 2 , treatments 3 and 4 vs 2). Withholding $1 / 3$ of the standard dose for 30 days improved juice quality but not

5 The standard dose of $1.5 \mathrm{~g}$ active material was received by about 40 plants bearing: roughly $90 \mathrm{~m}^{2}$ of accessible green-leaf surface. By way of comparison, field-test levels for Polaris have ranged from 2 to $8 \mathrm{~kg} / \mathrm{ha}$, probably involving in the order of 12,000 plants/ ha, plus a comparatively inaccessible green-leaf surface. 
yield (table 2, treatment 6 vs 2). Juice yield was significantly increased by increment treatments that reduced the initial dosage to $1 / 3$ of the standard (table 2, treatments $3-5$ vs 2). Yield increases were generally consonant with an improved growth performance (table 3) and leafcanopy development (table 4) attending the multiple applications. Each Polaris treatment produced characteristic, but essentially similar, effects on tissue sugar and protein components (table 5).

\section{DISCUSSION}

From present evidence, the efficiency of Polaris in modifying juice quality and yield appears to stem from two distinct types of plant regulation. One is a trend toward quality improvement, induced at a.

TABLE 1. - Number and frequency variations for a single quantity of Polaris administered to early-adult sugarcane

\begin{tabular}{clc}
\hline $\begin{array}{c}\text { Treat- } \\
\text { ment } \\
\text { number }\end{array}$ & \multicolumn{1}{c}{ Treatment } & \multicolumn{1}{c}{ Description } \\
\hline 1 & Control & Distilled water plus wetting agent \\
2 & Std. Polaris & $1.5 \mathrm{~g}$ active material applied at 0 day \\
3 & Early increments & $.5 \mathrm{~g}$ applied at 0,3 , and 6 days \\
4 & Delayed increments & $.5 \mathrm{~g}$ applied at 0,15 , and 30 days \\
5 & $1 / 3$ std., plus $2 / 3$ & $.5 \mathrm{~g}$ applied at 0 day, plus $1.0 \mathrm{~g}$ at 30 days \\
6 & $2 / 3$ std., plus ${ }^{1 / 3}$ & $1.0 \mathrm{~g}$ applied at 0 day, plus $0.5 \mathrm{~g}$ at 30 days \\
\hline
\end{tabular}

TABLE 2.-Juice quality and yield as a function of the number and frequency of Polaris applications

\begin{tabular}{|c|c|c|c|c|c|c|c|c|c|c|}
\hline \multirow{3}{*}{$\begin{array}{l}\text { Treat- } \\
\text { ment } \\
\text { num- } \\
\text { ber }\end{array}$} & \multirow{3}{*}{ Treatment ${ }^{1}$} & \multicolumn{9}{|c|}{ Mean values, at 0 and 49 days, for - } \\
\hline & & \multicolumn{3}{|c|}{ Brix } & \multicolumn{3}{|c|}{ Polarization } & \multicolumn{3}{|c|}{ Yield (ml/stem) } \\
\hline & & 0 & 49 & $\begin{array}{c}\% \\
\text { change }\end{array}$ & 0 & 49 & $\begin{array}{c}\% \\
\text { change }\end{array}$ & 0 & 49 & $\begin{array}{c}\% \\
\text { change }\end{array}$ \\
\hline 1 & Control & $7.4 b^{2}$ & $11.7 \mathrm{c}$ & $58.1 \mathrm{c}$ & $13.2 \mathrm{c}$ & $29.8 \mathrm{c}$ & $125.8 \mathrm{~d}$ & $28.3 \mathrm{a}$ & $72.7 \mathrm{a}$ & $156.9 \mathrm{a}$ \\
\hline 2 & $\begin{array}{l}\text { Std. } \\
\text { Polaris }\end{array}$ & $7.5 \mathrm{~b}$ & $17.3 \mathrm{~b}$ & $130.6 \mathrm{~b}$ & $13.8 \mathrm{c}$ & $51.2 \mathrm{~b}$ & $271.0 \mathrm{a}$ & $28.0 \mathrm{a}$ & $26.3 \mathrm{~d}$ & $-6.1 \mathrm{~d}$ \\
\hline 3 & $\begin{array}{l}\text { Early in- } \\
\text { crements }\end{array}$ & $8.3 \mathrm{a}$ & $17.5 \mathrm{~b}$ & $110.8 \mathrm{~b}$ & $17.6 \mathrm{ab}$ & $53.8 \mathrm{~b}$ & $205.7 \mathrm{bc}$ & $23.0 \mathrm{a}$ & $37.7 \mathrm{c}$ & $63.9 \mathrm{~b}$ \\
\hline 4 & $\begin{array}{l}\text { Delayed in- } \\
\text { crements }\end{array}$ & $8.8 \mathrm{a}$ & $16.8 \mathrm{a}$ & $90.9 \mathrm{~b}$ & $17.2 \mathrm{ab}$ & $50.9 \mathrm{~b}$ & $195.9 \mathrm{c}$ & $28.7 \mathrm{a}$ & $36.3 \mathrm{c}$ & $26.5 \mathrm{c}$ \\
\hline 5 & $\begin{array}{l}\text { 1/3 std. } \\
\text { plus } 2 / 3^{3}\end{array}$ & $8.5 \mathrm{a}$ & $18.1 \mathrm{~b}$ & $112.9 \mathrm{~b}$ & $16.7 \mathrm{abc}$ & $57.5 \mathrm{~b}$ & $244.3 \mathrm{ab}$ & $27.7 \mathrm{a}$ & $47.3 \mathrm{~b}$ & $70.8 \mathrm{~b}$ \\
\hline 6 & $\begin{array}{l}2 / 3 \text { std. } \\
\text { plus } 1 / 3^{3}\end{array}$ & $8.4 \mathrm{a}$ & $21.1 \mathrm{a}$ & $151.2 \mathrm{a}$ & $18.6 \mathrm{a}$ & $67.0 \mathrm{a}$ & $260.2 \mathrm{a}$ & $23.0 \mathrm{a}$ & $20.3 \mathrm{~b}$ & $-7.4 \mathrm{~d}$ \\
\hline
\end{tabular}

' Polaris was administered at $0900 \mathrm{~h}$ as an aqueous foliar spray containing $0.10 \%$ Tween 20.

${ }^{2}$ Mean values in the same column bearing unlike letters differ significantly $(\mathrm{P}<.05)$.

${ }^{3}$ The second fraction of the standard Polaris dosage was administered 30 days after the first fraction. 
TABLE 3.-Growth responses of Polaris in early-adult sugarcane as a function of the number and frequency of applications

\begin{tabular}{|c|c|c|c|c|c|c|c|c|c|c|}
\hline \multirow{3}{*}{$\begin{array}{l}\text { Treatment } \\
\text { number }\end{array}$} & \multirow{3}{*}{ Treatment' } & \multicolumn{9}{|c|}{ Green wt values (g/plant), at 0 and 49 days, for - } \\
\hline & & \multicolumn{3}{|c|}{ Total green wt } & \multicolumn{3}{|c|}{ Top wt } & \multicolumn{3}{|c|}{ Stem wt } \\
\hline & & 0 & 49 & $\begin{array}{c}\% \\
\text { change }\end{array}$ & 0 & 49 & $\begin{array}{c}\% \\
\text { change }\end{array}$ & 0 & 49 & $\begin{array}{c}\% \\
\text { change }\end{array}$ \\
\hline 1 & Control & $223 \mathrm{a}^{2}$ & $431 \mathrm{a}$ & $93.3 \mathrm{a}$ & $155 \mathrm{a}$ & $221 \mathrm{a}$ & $42.6 \mathrm{a}$ & $68 \mathrm{a}$ & 209 a & $207.4 \mathrm{a}$ \\
\hline 2 & Std. Polaris & 214 a & $161 \mathrm{e}$ & $-24.8 \mathrm{~d}$ & 151 a & $80 \mathrm{c}$ & $-47.0 \mathrm{c}$ & $63 \mathrm{a}$ & $81 \mathrm{c}$ & $28.6 \mathrm{c}$ \\
\hline 3 & Early increments & 216 a & $234 \mathrm{~d}$ & $8.3 \mathrm{c}$ & 149 a & $91 \mathrm{c}$ & $-38.9 c$ & $67 \mathrm{a}$ & $143 \mathrm{~b}$ & $113.4 \mathrm{~b}$ \\
\hline 4 & Delayed increments & $211 \mathrm{a}$ & $264 \mathrm{e}$ & $25.1 \mathrm{bc}$ & $147 \mathrm{a}$ & $129 \mathrm{~b}$ & $-12.2 \mathrm{bc}$ & 63 a & $135 \mathrm{~b}$ & $114.3 \mathrm{~b}$ \\
\hline 5 & $1 / 3$ std., plus $2 / 3^{3}$ & $215 \mathrm{a}$ & $323 \mathrm{~b}$ & $50.2 \mathrm{~b}$ & $150 \mathrm{a}$ & $162 \mathrm{~b}$ & $8.0 \mathrm{ab}$ & $65 \mathrm{a}$ & $161 \mathrm{~b}$ & $147.7 \mathrm{~b}$ \\
\hline 6 & $2 / 3$ std., plus $1 / 3^{3}$ & $200 \mathrm{a}$ & $162 \mathrm{e}$ & $-19.0 \mathrm{~d}$ & $141 \mathrm{a}$ & $77 \mathrm{c}$ & $-45.4 \mathrm{c}$ & $59 \mathrm{a}$ & $85 \mathrm{c}$ & $44.1 \mathrm{c}$ \\
\hline
\end{tabular}

${ }^{1}$ Polaris was administered at $0900 \mathrm{~h}$ as an aqueous foliar spray containing 0.10 Tween 20 .

${ }^{2}$ Mean values in the same column bearing unlike letters differ significantly $(\mathrm{P}<.05)$.

${ }^{3}$ The second fraction of the standard Polaris dosage was administered 30 days after the first fraction. 
single period in time in response to a fairly critical concentration of ripener. Once set in motion, quality improvement tended to "plateau" and was not appreciably modified by dispersing Polaris with early or delayed increments.

A second trend, toward growth repression, was also initiated at a single period in time but was intensified by initial ripener levels exceeding those producing optimal quality improvement. As a consequence of the two kinds of activity, maximum sucrose yield appears to require initial Polaris levels sufficiently high to attain a qualitative plateau, but low enough to minimize growth repression and injury to the foliar canopy.

TABLE 4.-Polaris effects on leaf canopy development as a function of the number and frequency of applications

\begin{tabular}{|c|c|c|c|c|c|c|}
\hline $\begin{array}{l}\text { Treat- } \\
\text { ment } \\
\text { num } \\
\text { ber }\end{array}$ & Treatment' & $\begin{array}{c}\text { Green } \\
\text { leaves/ } \\
\text { plant }\end{array}$ & $\begin{array}{l}\text { Chloro- } \\
\text { phyll }\end{array}$ & Area/blade $^{2}$ & $\begin{array}{l}\text { Phota- } \\
\text { synthetic } \\
\text { area/plant }\end{array}$ & $\begin{array}{l}\text { Photo- } \\
\text { synthetic } \\
\text { area as } \% \text { of } \\
\text { control }\end{array}$ \\
\hline & & Number & $\mathrm{Mg} / \mathrm{g}$ & $\mathrm{Cm}^{2}$ & $\mathrm{Cm}^{2}$ & \\
\hline 1 & Control & $7.6 \mathrm{a}^{3}$ & $1.85 \mathrm{a}$ & 417 a & $3,169 \mathrm{a}$ & 100.0 \\
\hline 2 & Std. Polaris & $2.1 \mathrm{c}$ & $.74 \mathrm{c}$ & $327 \mathrm{~d}$ & $678 \mathrm{c}$ & 21.7 \\
\hline 3 & Early increments & $2.6 \mathrm{c}$ & $.74 \mathrm{c}$ & $390 \mathrm{ab}$ & $1,014 \mathrm{c}$ & 32.0 \\
\hline 4 & Delayed increments & $4.2 \mathrm{~b}$ & $1.22 \mathrm{~b}$ & $384 \mathrm{abc}$ & $1,613 \mathrm{~b}$ & 50.9 \\
\hline 5 & $1 / 3$ std., plus $2 / 3^{4}$ & $4.9 \mathrm{~b}$ & $1.41 \mathrm{~b}$ & $363 \mathrm{bcd}$ & $1,779 \mathrm{~b}$ & 56.11 \\
\hline 6 & $2 / 3$ std., plus $1 / 3^{4}$ & $2.2 \mathrm{c}$ & $.81 \mathrm{c}$ & $338 \mathrm{~cd}$ & $774 \mathrm{c}$ & 23.5 \\
\hline
\end{tabular}

${ }^{1}$ Polaris was administered at $0900 \mathrm{~h}$ as an aqueous foliar spray containing $0.10 \%$ Tween 20.

2 Area measurements were performed with leaf rank +2 .

${ }^{3}$ Mean values in the same column bearing unlike letters differ significantly $(\mathrm{P}<.05)$.

${ }^{4}$ The second fraction of the standard Polaris dosage was administered 30 days after the first fraction.

\section{QUALITY AND YIELD RESPONSES TO MULTIPLE APPLICATIONS}

Present efforts to improve Polaris efficiency by use of early and long term increments were motivated by prior successes with the cane ripener and growth stimulant gibberellic acid (1). Gibberellic acid in short term increments nearly doubled the hormone's growth performance, as opposed to a single application or delayed increments. However, multiple applications of Polaris improved juice quality over that of the standard dose in only one treatment, where $2 / 3$ of the standard was given at 0 days (table 2, treatment 6 vs 2). In this instance the repressive effects against juice yield, growth, and canopy development (tables 2-4) were comparable to the standard Polaris treatment and no added benefits are seen to accrue. The failure to improve Polaris efficiency by dispersing its action is consistent with earlier results showing that decisive Polaris effects are produced on the day of its application (4). 
TABLE 5. - Polaris effects on meristematic sugar and protein components as a function of the number and frequency of applications

\begin{tabular}{|c|c|c|c|c|c|c|c|c|c|c|c|c|}
\hline \multirow{3}{*}{ Treatment $^{1}$} & \multicolumn{9}{|c|}{$\mathrm{Mg} / \mathrm{g}$ dry wt, at 0 and 49 days, for - } & \multicolumn{3}{|c|}{$\begin{array}{c}\text { Acid invertase } \\
\text { (mg product/g tissue/h) }\end{array}$} \\
\hline & \multicolumn{3}{|c|}{ Sucrose } & \multicolumn{3}{|c|}{ Reducing sugar } & \multicolumn{3}{|c|}{ Soluble protein } & \multirow[b]{2}{*}{0} & \multirow[b]{2}{*}{49} & \multirow{2}{*}{$\begin{array}{c}\% \\
\text { change }\end{array}$} \\
\hline & 0 & 49 & $\begin{array}{c}\% \\
\text { change }\end{array}$ & 0 & 49 & $\begin{array}{c}\% \\
\text { change }\end{array}$ & 0 & 49 & $\begin{array}{c}\% \\
\text { change }\end{array}$ & & & \\
\hline Control & $86 a^{2}$ & $100 \mathrm{c}$ & $16 \mathrm{~b}$ & $94 \mathrm{a}$ & 87 a & $-8 \mathrm{~d}$ & 58 a & $102 \mathrm{a}$ & $76 \mathrm{a}$ & $28.3 \mathrm{ab}$ & $29.2 \mathrm{a}$ & $3.2 \mathrm{a}$ \\
\hline Std. Polaris & $92 \mathrm{a}$ & $235 \mathrm{ab}$ & $155 \mathrm{a}$ & $98 \mathrm{a}$ & $33 c$ & $-66 a$ & $62 \mathrm{a}$ & $23 \mathrm{~b}$ & $-63 \mathrm{~b}$ & $24.1 \mathrm{c}$ & $4.8 \mathrm{~b}$ & $-80.1 \mathrm{~b}$ \\
\hline Early increments & $88 \mathrm{a}$ & $248 \mathrm{a}$ & $182 \mathrm{a}$ & $105 \mathrm{a}$ & $77 \mathrm{a}$ & $-27 \mathrm{c}$ & $64 \mathrm{a}$ & $27 \mathrm{~b}$ & $-58 \mathrm{~b}$ & $31.6 \mathrm{a}$ & $4.5 \mathrm{~b}$ & $-85.8 \mathrm{~b}$ \\
\hline Delayed increments & $94 \mathrm{a}$ & $234 \mathrm{ab}$ & $149 \mathrm{a}$ & $103 a$ & $54 \mathrm{~b}$ & $-48 \mathrm{~b}$ & $63 \mathrm{a}$ & $26 \mathrm{~b}$ & $-59 \mathrm{~b}$ & $28.8 \mathrm{a}$ & $2.5 \mathrm{c}$ & $-91.3 \mathrm{~b}$ \\
\hline $1 / 3$ std., plus ${ }^{2} / 3^{3}$ & $90 \mathrm{a}$ & $227 \mathrm{~b}$ & $152 \mathrm{a}$ & $97 \mathrm{a}$ & $55 \mathrm{~b}$ & $-43 b c$ & $54 \mathrm{a}$ & $24 \mathrm{~b}$ & $-56 \mathrm{~b}$ & $24.5 \mathrm{~b}$ & $1.9 \mathrm{c}$ & $-92.2 \mathrm{~b}$ \\
\hline $2 / 3$ std., plus $1 / 3^{3}$ & $91 \mathrm{a}$ & $247 \mathrm{a}$ & $171 \mathrm{a}$ & $100 \mathrm{a}$ & $32 \mathrm{c}$ & $-68 a$ & $63 \mathrm{a}$ & $17 \mathrm{~b}$ & $-73 b$ & $30.9 \mathrm{a}$ & $2.8 \mathrm{c}$ & $-90.9 b$ \\
\hline
\end{tabular}

${ }^{1}$ Polaris was administered at $0900 \mathrm{~h}$ as an aqueous foliar spray containing $0.10 \%$ Tween 20.

${ }^{2}$ Mean values in the same column bearing unlike letters differ significantly $(\mathrm{P}<.05)$.

${ }^{3}$ The second fraction of the standard Polaris dosage was administered 30 days after the first fraction. 
Polaris treatments in which the 0 -day application was lowered to $1 / 3$ of the standard dosage produced significantly greater juice yields at 49 days (table 2 , treatments $3-5$ vs 2 ). Because juice quality values were essentially comparable for all Polaris treatments at this time (table 2, treatments 2-6), the use of increments quantitatively increased recoverable sucrose. The most efficient treatment in terms of juice yield was ${ }^{1 / 3}$

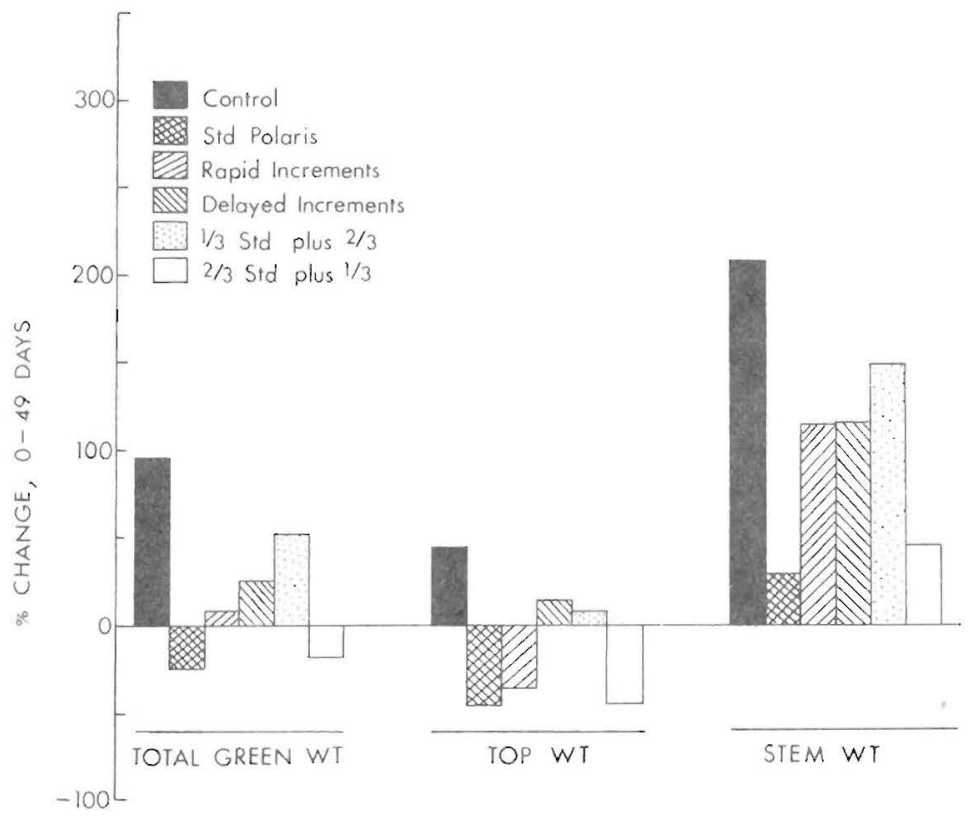

FIC. 1. - Sugarcane growth responses to a single quantity of Polaris administered in variable increments.

of the standard dose given at 0 days plus $2 / 3$ at 30 days (table 2, treatment 5).

\section{GROWTH AND CANOPY-DEVELOPMENT RESPONSES}

The more favorable juice yields obtained by dispersing Polaris can be traced to an alleviation of growth and canopy-development restrictions imposed by the standard dosage (tables 3 and 4, treatments 3-5 vs 2). The principal gain was in stem weights (fig. 1). Top weight remained severely restricted by Polaris supplied in early increments (table 3, treatment 3 vs 2). The partial relief from growth repression conforms with earlier findings in which growth alleviation by specific diurnal treatments was accompanied by increased sucrose yield (4). 
While canopy improvement was small in terms of total green weight, the condition of increment-treated canopies was visibly superior to those given the standard Polaris treatment. This trend is clearly reflected in individual foliar parameters (table 4). Standard Polaris caused a severe loss of leaf ranks owing to spindle repression at a time when aging leaves continued to detach from the stem. At 49 days, ranks ${ }^{+} 1$ and ${ }^{+} 2$ for standard Polaris were equal in age to ranks ${ }^{+} 6$ and +7 of control plants. There was an attendant loss of chlorophyll common to aged leaves, and of viable green-leaf area through desiccation of blade tips and margins. These features were partially corrected by lowering the initial Polaris level to $1 / 3$ of the standard dose, although all ripener-treated canopies remained inferior to the untreated control. The quantitative and qualitative improvement of source tissues helps to account for the continued high juice quality of increment-treated cane where some level of plant growth was maintained.

\section{RESUMEN}

La eficiencia de Polaris para modificar la calidad del jugo, el rendimiento y crecimiento de la caña de azúcar se estudió en plantas jóvenes adultas propagadas en arena. Una sola cantidad del agente madurativo administrada en una dosis sirvió como el tratamiento regular de Polaris. Se aplicaron cantidades iguales como incrementos acelerados $(0,3$ y 6 dias) y como incrementos retrasados $(0,15$ y 30 días). Otros tratamientos suministraron $1 / 3$ más $2 / 3$ de la dosis regular de 0 a 30 días, respectivamente, y en el orden invertido de $2 / 3$ más $1 / 3$. La administración de Polaris en incrementos acelerados o retrasados no aumentó la calidad del jugo, pero sí el rendimiento significativamente sobre la dosis regular. El rendimiento de jugo luego aumentó al retener $2 / 3$ de la dosis regular hasta 30 días. Este aumento indica un mejoramiento en las restricciones de crecimiento y desarrollo del dosel impuesto por el tratamiento regular de Polaris. Estos resultados fueron interpretados en términos de las funciones cualitativas y regularizadoras de crecimiento de Polaris, en los cuales la reducción del crecimiento continuó intensificándose a niveles de madurez en exceso de aquéllos necesarios para logar una calidad óptima.

\section{LITERATURE CITED}

1. Alexander, A. G., Montalvo-Zapata, R., and Kumar, A., Gibberellic acid activity in sugarcane as a function of the number and frequency of application, J. Agr. Univ. P.R. 54(3): 477-503, 1970.

2. - and - Evaluation of chemical ripeners for sugarcane having constant nitrogen and water regimes. I. Growth, quality and enzymic responses of nine potential ripeners, Tropical Agr. 49: 35-44, 1973.

3. - Sugarcane Physiology. A comprehensive study of the Saccharum Source-toSink System, Elsevier Scientific Publishing Co., Amsterdam, 1973.

4. - Efficiency of chemical ripener action in sugarcane. I. Growth and quality responses to Polaris applied at different hours of the day, J. Agr. Univ. P.R. 60(4): $460-8,1976$.

5. Anonymous, More sucrose with Polaris, Commercial release by Monsanto Agricultural Products Co., January 1975.

6. Arnon, D. I., Copper enzymes in isolated chloroplasts. Polyphenol-oxidase in Beta vulgaris, Plant Physiol. 24: 1-15, 1949.

7. Samuels, G., and Vélez-Ramos, A., Field experiments with Polaris as a chemical ripener of sugarcane in Puerto Rico, 1970-72, J. Agr. Univ. P.R. (In press). 